\title{
UJI AKTIVITAS ANTIOKSIDAN EKSTRAK ETANOL BIJI BUAH MERAH (Pandanus conoideus de vriese) ASAL KABUPATEN POSO SULAWESI TENGAH
}

\author{
The Test Antioxidant Activity from Ethanol Extract of Red Fruit Seeds (Pandanus conoideus de \\ vriese) from Poso Central Sulawesi
}

\author{
*Siti Sulaeha, Minarni Rama Jura, dan Nurdin Rahman \\ Pendidikan Kimia/FKIP - Universitas Tadulako, Palu - Indonesia 94118 \\ Received 12 June 2017, Revised 11 July 2017, Accepted 11 August 2017
}

\begin{abstract}
Red fruit seeds have not been studied and known benefits, therefore it needed scientific information about the contentand benefits of red fruit seeds. This study aims to analyze the antioxidant power red fruit seed extract as well determining the $I C_{50}$ value of red fruit seed extract which has the ability of natural antioxidants. Determination of free radical DPPH (1,1-diphenyl-2-picrylhidrazyl) after the addition of red fruit seeds extract is determined using $U V$-Vis spectrophotometer. Variations in the concentration of the red fruit seed extract used is $20 \mathrm{ppm}, 40 \mathrm{ppm}, 60$ ppm, $80 \mathrm{ppm}$ and $100 \mathrm{ppm}$. The positive control used is vitamin $C$ with the same concentration. While the negative control using DPPH solution dissolved in absolute ethanol. The results showed $I C_{50}$ values obtained for the red fruit seed extract and vitamin $C$ are $223.8 \mathrm{ppm}$ and $1.73 \mathrm{ppm}$. Based on the IC $C_{50}$ data can be known that vitamin $C$ antioxidants more powerful than red fruit seed extract which belongs to natural antioxidantsare very weak.
\end{abstract}

Keywords: Antioxidants, reed fruit seed extract, DPPH, UV-Vis spectrophotometer.

\section{Pendahuluan}

Indonesia sangat kaya akan tumbuhan obat alam yang telah digunakan oleh masyarakat kita sejak dulu berdasarkan pengalaman secara turun temurun. Obat tradisional dari bahan alam dapat menjadi salah satu alternatif pengobatan apalagi di tengah situasi perekonomian di mana salah satu konsekuensinya adalah tingginya harga obat sintetik (Makaruku, 2008). Bahan alami dari tumbuhan yang bermanfaat sebagai obat sudah banyak digunakan, baik di bidang industri obat maupun pengobatan tradisional.Salah satu tumbuhan yang saat ini banyak diteliti karena secara empiris banyak dimanfaatkan sebagai obat tradisional oleh masyarakat lokal Papua adalah buah merah. Buah yang termasuk dalam family Pandanaceae ini oleh masyarakat Papua secara empiris telah dimanfaatkan selain baik sebagai obat tradisional juga sebagai zat pewarna alami dan sumber bahan makanan (Budi \& Paimin, 2005).

Sampai saat ini, pemanfaatan buah merah hanya terfokus pada daging buahnya.Padahal selain daging buah merah, bagian lain dari buah merah adalah biji buahnya. Jumlah biji buah merah cukup melimpah karena buah merah tersusun atas ribuan biji, sehingga sekilas bentuknya menyerupai kulit nangka dengan panjang biji sekitar $1 \mathrm{~cm}$ dan diameter $0,2 \mathrm{~cm}$. Selama ini, bijinya dibuang begitu saja setelah daging buahnya diambil. Padahal, buah dan biji saling berkaitan erat karena keduanya mempunyai susunan struktur hampir sama dan sama-sama berfungsi

${ }^{*}$ Correspondence

Siti Sulaeha

Program Studi Pendidikan Kimia, Fakultas Keguruan dan IImu Pendidikan, Universitas Tadulako

e-mail: sulaeha.pombili@gmail.com

Published by Universitas Tadulako 2017 sebagai tempat penyimpanan cadangan makanan dalam tumbuhan(Suharto, 2004).

Buah merah (Pandanus conoideus de vriese) juga terdapat di daerah Poso Sulawesi Tengah dengan ketinggian pohon 6-10 meter dari permukaan tanah, memiliki panjang buah sekitar $\pm 38 \mathrm{~cm}$ dan memiliki diameter $\pm 8 \mathrm{~cm}$ yang tumbuh di daerah pegunungan dengan jarak \pm 150.000 meter dari pantai (Gambar 1). Kebanyakan masyarakat Poso belum mengetahui manfaat dan khasiat dari buah merah. Mereka hanya mengetahui yang terdapat di daerah Papua (Yulianti, dkk., 2015).

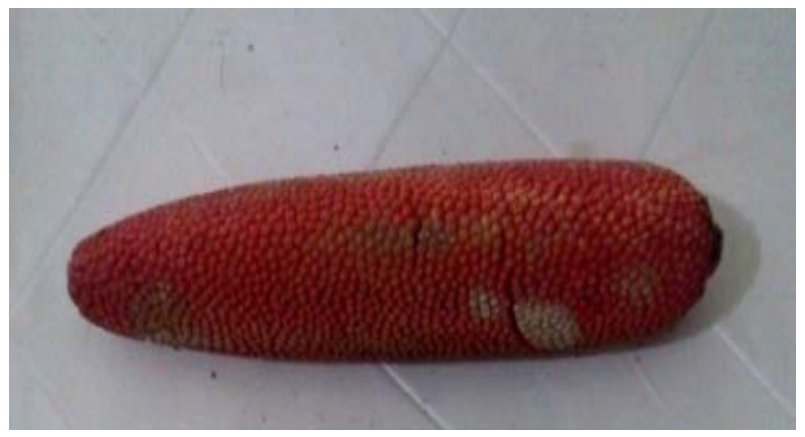

Gambar 1. Buah merah (Pandanus conoideus de vriese) asal Poso

Sangkala, dkk. (2014) telah melakukan uji pendahuluan terhadap ekstrak buah merah dari daerah Poso Sulawesi Tengah, dimana ekstrak buah merah menunjukkan hasil positif terhadap golongan senyawa flavonoid dan tanin, serta negatif terhadap alkaloid dan saponin.Sejalan dengan penelitian sebelumnya serta berdasarkan adanya keterkaitan erat antara biji dan buah tidak menutup kemungkinan bahwa senyawa yang terkandung di dalam daging buah merah juga dapat ditemukan dalam biji buah walaupun berbeda kuantitasnya. Tulisan ini 
dimaksudkan untuk mengurai kajian potensi biji buah merah sebagai antioksidan.

\section{Metode}

Alat-alat yang digunakan pada penelitian adalah Spektrofotometer UV-Vis (Lambda 25), neraca analitik (AND GR-200), blender, vacuum rotary evaporator (Eyela SB-1100), magnetic stirrer, aluminium foil, kertas saring serta peralatan gelas yang umum digunakan dalam laboratorium. Bahanbahan yang digunakan yaitu ekstrak biji buah merah, etanol absolute (Merck), padatan 1,1-difenil-2pikrilhidrazil (DPPH) (Merck), padatan vitamin C (asam askorbat) (Merck), serbuk logam $\mathrm{Mg}$ (Merck), $\mathrm{HCl}$ pekat (Merck), $\mathrm{NaOH} 10 \%$ (Merck), $\mathrm{FeCl}_{3}$ $($ Merck), dan akuades.

\section{Preparasi sampel}

Sampel biji buah merah dibersihkan dengan cara memisahkan biji buah merah dari kulit dan daging buahnya. Biji buah merah dicuci dengan air mengalir sampai bersih, kemudian dikeringkan dengan cara dianginkan-anginkan terlindung dari sinar matahari langsung selama 7 hari. Sampel kemudian dipotong kecil-kecil.Hasil potongan dikeringkan kembali selama 2 hari agar sampel benar-benar kering.Kemudian dihaluskan dengan menggunakan blender.Sampel biji buah merah kemudian diekstrak untuk mengisolasi senyawa metabolit sekunder yang terkandung di dalamnya.

\section{Ekstraksi dengan etanol}

Ekstrak dibuat dengan menggunakan metode maserasi dengan cara merendam sebanyak 30 gram sampel biji buah merah dengan $300 \mathrm{~mL}$ larutan etanol absolut disertai dengan pengadukan selama 3 jam dan didiamkan selama 2x24 jam. Hasil ekstraksi kemudian disaring dan dipekatkan menggunakan vacuum rotary evaporator pada suhu $30^{\circ} \mathrm{C}$, hingga diperoleh ekstrak pekat biji buah merah. Setelah itu, ekstrak disimpan untuk pengujian aktivitas antioksidan.

\section{Uji aktivitas antioksidan}

Tahapan-tahapan dalam prosedur untuk pengujian aktivitas antioksidan mengikuti prosedur yang dilakukan oleh Molyneux, (2004).

\section{Pembuatan larutan}

$1,97 \mathrm{mg}$ padatan DPPH ditimbang dan dilarutkan dengan larutan etanol absolut dalam labu ukur $100 \mathrm{~mL}$ kemudian volumenya ditambahkan sampai tanda batas, sehingga diperoleh larutan DPPH dengan konsentrasi $50 \mu \mathrm{M}$.

$25 \mathrm{mg}$ ekstrak etanol biji buah merah ditimbang dan ditambahkan dengan larutan etanol absolut dalam labu ukur $25 \mathrm{~mL}$, kemudian volumenya ditambahkan sampai tanda batas.

$25 \mathrm{mg}$ padatan Vitamin C ditimbang dan ditambahkan larutan etanol absolut dalam labu ukur
$25 \mathrm{~mL}$, kemudian volumenya dicukupkan sampai tanda batas.

\section{Uji aktivitas antioksidan ekstrak etanol biji buah merah}

Larutan induk esktrak biji buah merah 1000 ppm dilakukan pengenceran secara bertahap sehingga diperoleh larutan sampel dengan konsentrasi 20, 40, 60, 80 dan 100 ppm. Penentuan aktivitas antioksidan dilakukan terhadap masing-masing konsentrasi dengan cara dipipet sebanyak $1 \mathrm{~mL}$ larutan sampel dan ditambahkan $4 \mathrm{~mL}$ larutan DPPH $50 \mu \mathrm{M}$. Campuran dihomogenkan dan dibiarkan selama 30 menit di tempat gelap pada suhu kamar. Absorbansi diukur dengan spektrofotometer UV-Vis pada panjang gelombang $518 \mathrm{~nm}$ dengan interval waktu 5 menit sampai diperoleh absorbansi yang stabil dan tidak terlihat adanya penurunan absorbansi.

\section{Uji antioksidan larutan pembanding vitamin $C$}

Vitamin $\mathrm{C}$ digunakan sebagai pembanding dengan konsentrasi masing-masing 20, 40, 60, 80 dan 100 ppm dengan perlakuan yang sama seperti sampel uji ekstrak etanol biji buah merah.

\section{Pengukuran aktivitas antioksidan}

Aktivitas antioksidan ditentukan dari $\mathrm{IC}_{50}$ dari senyawa antioksidan. Nilai $\mathrm{IC}_{50}$ diperoleh dari ploting terhadap persamaan regresi linear antara log konsentrasi dan nilai probit $\mathrm{IC}_{50}=\mathrm{A} \log \mathrm{X}$ (Rahman, dkk., 2008). Berdasarkan data kurva regresi isolat aktivitas antioksidan tersebut dapat ditentukan nilai $\mathrm{IC}_{50}$ dari senyawa antioksidan.

\section{Hasil dan Pembahasan}

Kajian ini diawali dengan melakukan uji fitokimia terhadap ekstrak etanol biji buah merah. Uji fitokimia menunjukkan hasil positif terhadap senyawa flavonoid dan tanin. Flavonoid dapat diuji keberadaannya menggunakan $\mathrm{Mg}$ dan $\mathrm{HCl}$ pekat. Senyawa flavonoid dapat menghasilkan warna merah, kuning atau jingga ketika tereduksi dengan $\mathrm{Mg}$ dan $\mathrm{HCl}$ (Harborne, 1987). Hasil skrining fitokimia menunjukkan ekstrak etanol biji buah merah berwarna jingga dan positif terdapat flavonoid.Contoh reaksi terbentuknya senyawa flavonoid ketika direduksi oleh $\mathrm{Mg}$ dan $\mathrm{HCl}$ ditunjukan pada Gambar 2.

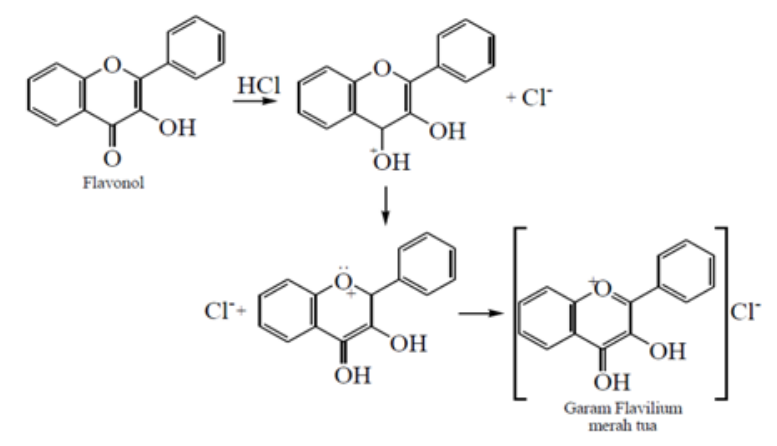


Gambar 2. Reaksi flavonoid dengan logam $\mathrm{Mg}$ dan $\mathrm{HCl}$ (Achmad, 1986)

Uji fitokimia senyawa tanin pada ekstrak biji buah merah ditandai dengan terbentuknya warna hijau kehitaman setelah ekstrak ditambahkan dengan $\mathrm{FeCl}_{3}$. Terbentuknya warna hijau kehitaman pada ekstrak setelah ditambahkan dengan $\mathrm{FeCl}_{3}$ karena tanin akan membentuk senyawa kompleks dengan ion $\mathrm{Fe}^{3+}$ seperti pada Gambar 3 .

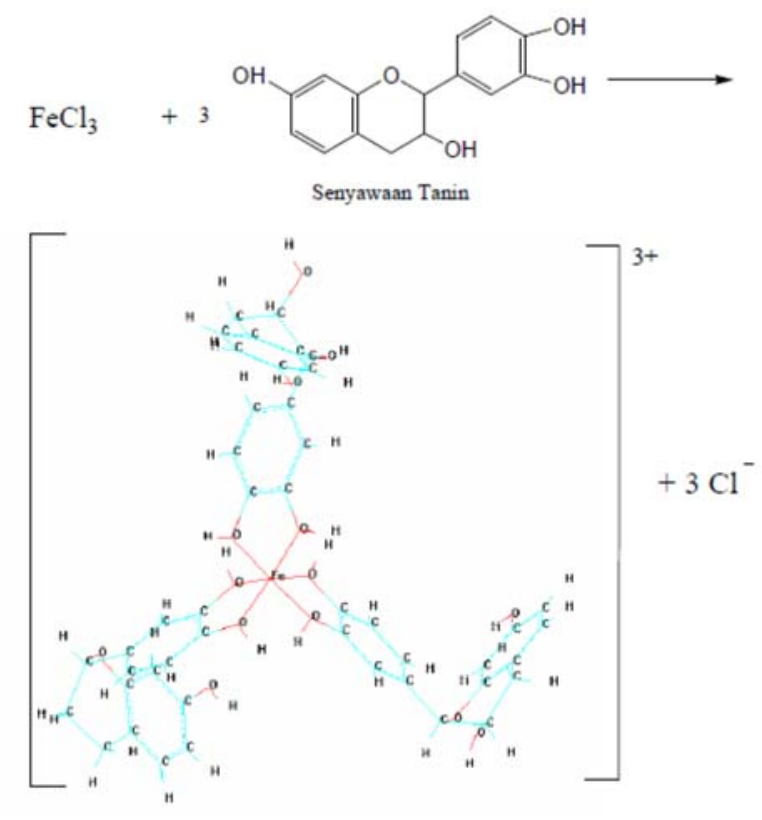

Gambar 3. Reaksi antara tanin dan $\mathrm{FeCl}$ (Sa'adah, 2010)

Terbentuknya senyawa kompleks antara tanin dan $\mathrm{FeCl}_{3}$ karena adanya ion $\mathrm{Fe}^{3+}$ sebagai atom pusat dan tanin memiliki atom $\mathrm{O}$ yang mempunyai pasangan elektron bebas yang bisa mengkoordinasikan ke atom pusat sebagai ligannya. Ion $\mathrm{Fe}^{3+}$ pada reaksi di atas mengikat tiga tanin yang memiliki 2 atom donor yaitu atom $\mathrm{O}$ pada posisi 4 dan 5 dihidroksi, sehingga ada 6 enam pasangan elektron bebas yang bisa dikoordinasikan ke atom pusat. Atom $\mathrm{O}$ pada posisi 4' dan 5' dihidroksi memiliki energi paling rendah dalam pembentukkan senyawa kompleks, sehingga memungkinkan menjadi sebuah ligan (Sa'adah, 2010).

\section{Uji aktivitas antioksidan}

Keberadaan senyawa antioksidan dalam suatu bahan dapat dideteksi dengan melakukan uji antioksidan.Metode yang digunakan pada penentuan aktivitas antioksidan biji buah merah pada kajian ini adalah dengan menggunakan metode uji DPPH. Metode uji aktivitas antioksidan menggunakan radikal bebas DPPH dipilih karena metode ini sederhana, mudah, cepat, peka dan hanya memerlukan sedikit sampel (Molyneux, 2004). Pengujian aktivitas antioksidan ekstrak biji buah merah diawali dengan penentuan panjang gelombang maksimum $\left(\lambda_{\text {maks }}\right)$ DPPH $50 \mu \mathrm{M}$ dalam etanol sebagai kontrol dengan menggunakan spektrofotometer UV-Vis untuk pengukuran ekstrak uji. Panjang gelombang maksimum yang diperoleh pada pengukuran ini yaitu pada panjang gelombang $518 \mathrm{~nm}$ dengan absorbansi sebesar 0,5966.

Senyawa dikatakan memiliki aktivitas antioksidan apabila senyawa tersebut mampu mendonorkan atom hidrogennya pada radikal bebas DPPH. Hal ini ditandai dengan perubahan warna ungu menjadi kuning (Molyneux, 2004). Perubahan warna tersebut terjadi pada ekstrak biji buah merah yang diberi larutan DPPH $50 \mu \mathrm{M}$ dan diinkubasi selama 30 menit pada suhu kamar.Perubahan ini terjadi karena DPPH berperan sebagai radikal bebas yang diredam oleh antioksidan dari sampel. Selanjutnya DPPH akan diubah menjadi DPPH-H (bentuk tereduksi $\mathrm{DPPH}$ ) oleh senyawa antioksidan. Reaksi antara antioksidan dan senyawa DPPH dapat dilihat pada Gambar 4
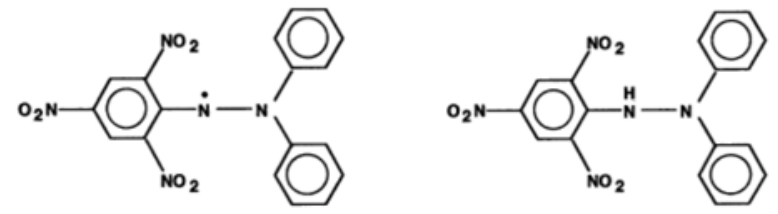

Gambar 4. Struktur kimia radikal bebas (1) dan bentuk non radikal (2) (Molyneux, 2004)

Absorbansi ekstrak biji buah merah dan vitamin C dapat dilihat pada Tabel 1. Berdasarkan nilai absorbansi pada ekstrak biji buah merah nilai absorbansi ekstrak biji buah merah semakin berkurang dengan meningkatnya konsentrasi. Hal ini dapat dijelaskan bahwa dengan adanya aktivitas antioksidan dari sampel mengakibatkan perubahan warna larutan DPPH yang berwarna ungu menjadi lebih terang seiring bertambahnya konsentrasi sampel (Silalahi \& Kusharyanti, 2006). Turunnya absorbansi menandakan berkurangnya konsentrasi radikal bebas dari DPPH yang dikarenakan oleh adanya reaksi dengan senyawa antioksidan yang mengakibatkan molekul DPPH tereduksi dan diikuti dengan berkurangnya intensitas warna ungu dari larutan DPPH. Jika semua elektron pada radikal bebas DPPH menjadi berpasangan, maka warna larutan berubah dari ungu tua menjadi kuning terang dan absorbansi pada panjang gelombang $518 \mathrm{~nm}$ akan hilang (Rohman, dkk., 2010).

Tabel 1. Nilai absorbansi ekstrak biji buah merah dan vitamin $\mathrm{C}$

\begin{tabular}{cccc}
\hline & \multirow{2}{*}{$\begin{array}{c}\text { Konsentrasi } \\
\text { No }\end{array}$} & \multicolumn{2}{c}{ Absorbansi } \\
\cline { 3 - 4 } & & $\begin{array}{c}\text { Ekstrak Buah } \\
\text { Merah }\end{array}$ & Vitamin C \\
\hline 1 & 20 & 0,4233 & 0,0474 \\
2 & 40 & 0,4072 & $-0,014$ \\
3 & 60 & 0,3761 & $-0,014$ \\
4 & 80 & 0,3764 & $-0,015$ \\
5. & 100 & 0,3207 & $-0,015$ \\
\hline
\end{tabular}


Nilai absorbansi vitamin $\mathrm{C}$ yang didapatkan pada pengukuran ini bernilai negatif pada konsentrasi 40 ppm dan 60 ppm serta $80 \mathrm{ppm}$ dan $100 \mathrm{ppm}$ memiliki nilai absorbansi yang sama yaitu $-0,014$ dan $-0,015$. Hal ini ditinjau dari perubahan warna yang terjadi.Pada penelitian ini, perubahan warna ungu menjadi kuning pada vitamin $\mathrm{C}$ lebih cepat dibandingkan dengan ekstrak biji buah merah.Pada vitamin C, setelah ditambahkan larutan DPPH warna larutannya seketika berubah menjadi kuning, sedangkan pada ekstrak biji buah merah memerlukan waktu lebih lama untuk berubah menjadi kuning.Perubahan warna ungu menjadi kuning pada uji aktivitas antioksidan menandakan terbentuknya radikal antioksidan.Semakin banyak atom $\mathrm{H}$ dari antioksidan yang didonorkan pada DPPH maka semakin banyak radikal antioksidan yang terbentuk (Suryanto, 2012).

\section{Perbandingan aktivitas penangkap radikal bebas ekstrak biji buah merah dan vitamin $C$}

Hasil penelitian ini membandingkan aktivitas antioksidan dalam menangkap radikal bebas antara ekstrak biji buah merah dan vitamin C sebagai kontrol positif.Persentase daya antioksidan vitamin $\mathrm{C}$ lebih tinggi dibandingkan ekstrak biji buah merah.Vitamin $\mathrm{C}$ memiliki aktivitas antioksidan yang tinggi karena vitamin $\mathrm{C}$ memiliki 2 gugus hidroksil yang mengakibatkan lebih mudah dalam pendonoran hidrogen.Perbandingan persentase penangkap radikal bebas dari ekstrak biji buah merah dapat dilihat pada Gambar 5.

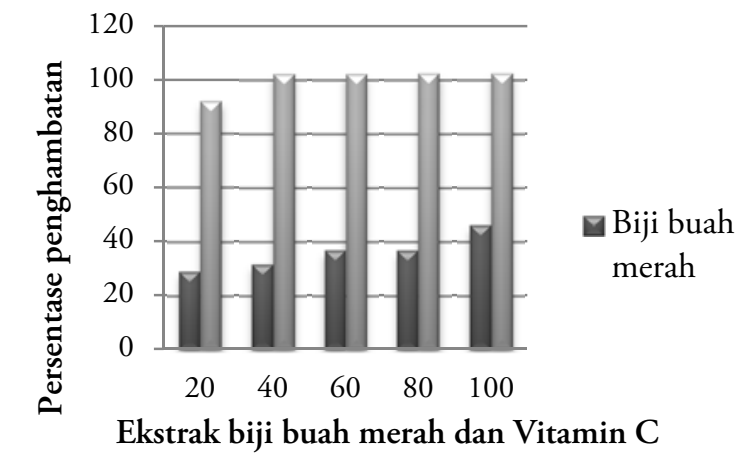

(ppm)

Gambar 5. Perbandingan persentase penghambatan ekstrak biji buah merah dan vitamin $\mathrm{C}$

Perbandingan persentase antioksidan antara ekstrak biji buah merah dan vitamin C dalam menangkap radikal bebas berbeda secara signifikan. $\mathrm{Hal}$ ini disebabkan vitamin $\mathrm{C}$ merupakan senyawa murni sehingga di dalamnya tidak ada senyawa lain yang dapat mengganggu proses peredaman radikal bebas (Silalahi \& Kusharyanti, 2006). Sedangkan untuk ekstrak biji buah merah dapat dikatakan sebagai zat antioksidan alami akan tetapi termasuk antioksidan alami sangat lemah. Sehingga ekstrak biji buah merah tidak dapat digunakan sebagai zat antioksidan alami.

\section{Hasil pengukuran $I C_{50}$}

Parameter yang digunakan untuk aktivitas antioksidan dengan metode penangkapan radikal $\mathrm{DPPH}$ ini adalah $\mathrm{IC}_{50}$ yaitu konsentrasi senyawa (ekstrak) uji yang dibutuhkan untuk mengurangi radikal DPPH sebesar 50\% (Zao, dkk., 2004). Harga $\mathrm{IC}_{50}$ didefinisikan sebagai konsentrasi efektif zat uji yang dapat menurunkan $50 \%$ intensitas serapan dibandingkan dengan kontrol. Nilai $\mathrm{IC}_{50}$ dari ekstrak biji buah merah dan vitamin $\mathrm{C}$ dapat dilihat pada Gambar 6 dan 7 yang menunjukkan persamaan garis hubungan antara log konsentrasi dan nilai probit.

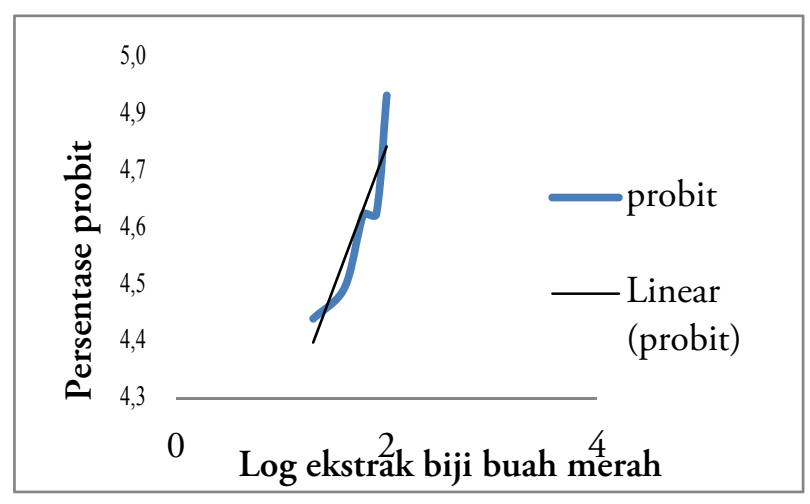

Gambar 6. Hubungan Log Konsentrasi dan Probit Ekstrak Biji Buah Merah

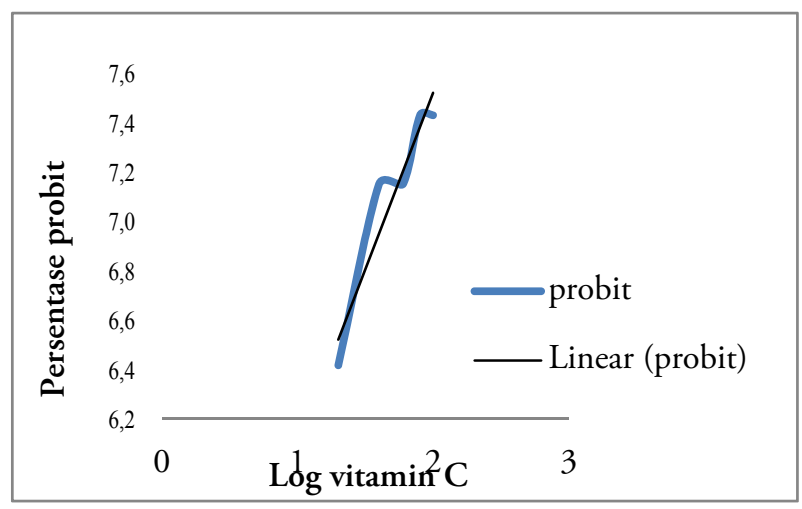

Gambar 7. Hubungan log konsentrasi dan probit vitamin $\mathrm{C}$

Berdasarkan Gambar 7 maka diperoleh nilai $r$ untuk ekstrak biji buah merah dan vitamin $\mathrm{C}$ sebagai kontrol positif, masing-masing 0,809 dan 0,907. Nilai $r$ tersebut mengindikasikan bahwa nilai probit ekstrak vitamin C lebih baik dibandingkan nilai probit ekstrak biji buah merah, dari tinjauan literatur jika grafik hasil perhitungan memiliki nilai $r$ mendekati 1 atau sama dengan 1 , maka data yang diperoleh sangat baik. Oleh karenanya nilai $r$ yang diperoleh vitamin $\mathrm{C}$ dapat dikatakan sangat baik sedangkan ekstrak biji buah merah dikatakan kurang baik. Beberapa hal yang mempengaruhi nilai $r$ kurang maksimal yakni: (1) kurang baiknya pembuatan deret konsentrasi larutan yang digunakan (2) instrument 
spektofotometer UV-Vis yang tidak dikalibrasi secara benar dan (3) adanya pengotor dalam tabung reaksi yang digunakan sebagai tempat awal larutan (Day, 2003).

Nilai $\mathrm{IC}_{50}$ yang diperoleh dari perhitungan akhir yaitu untuk ekstrak biji buah merah diperoleh $\mathrm{IC}_{50}$ sebesar 223,8 ppm sedangkan $\mathrm{IC}_{50}$ yang diperoleh vitamin $C$ sebesar $1,73 \mathrm{ppm}$. Kemampuan radikal bebas ekstrak biji buah merah tergolong sangat lemah dikarenakan nilai $\mathrm{IC}_{50}$ yang diperoleh dari perhitungan lebih dari $200 \mathrm{ppm}$ yaitu 223,8 ppm. Hal ini sesuai literatur yang mengatakan bahwa suatu senyawa dikatakan sebagai antioksidan sangat kuat apabila memiliki $\mathrm{IC}_{50}$ kurang dari $50 \mathrm{ppm}$, kuat apabila nilai $\mathrm{IC}_{50}$ antara $50-100 \mathrm{ppm}$, sedang apabila nilai $\mathrm{IC}_{50}$ antara $100-150$, lemah apabila nilai $\mathrm{IC}_{50}$ berkisar antara 150-200 ppm, sangat lemah apabila nilai $\mathrm{IC}_{50}$ lebih dari 200 ppm (Molyneux, 2004).

Berdasarkan nilai $\mathrm{IC}_{50}$ yang diperoleh dapat dijelaskan pula bahwa vitamin $\mathrm{C}$ sebagai pembanding atau kontrol positif mempunyai daya antioksidan yang lebih kuat dibandingkan ekstrak biji buah merah yang digunakan sebagai sampel, hal ini dapat dilihat dari nilai $\mathrm{IC}_{50}$ vitamin $\mathrm{C}$ yang diperoleh sebesar 1,73 ppm, dimana nilai $\mathrm{IC}_{50}$ vitamin $\mathrm{C}$ tergolong sangat kuat karena kurang dari 50 ppm.

\section{Kesimpulan}

Ekstrak etanol biji buah merah memiliki aktivitas sangat lemah sebagai penangkap radikal bebas dengan senyawa radikal DPPH. Ekstrak etanol biji buah merah menunjukkan aktivitas antioksidan dengan nilai $\mathrm{IC}_{50}$ sebesar 223,8 ppm. Dengan demikian, ekstrak biji buah merah tidak dapat digunakan sebagai bahan antioksidan alami karena tergolong antioksidan yang sangat lemah dalam menghambat radikal bebas.

\section{Ucapan Terima Kasih}

Penulis mengucapkan terima kasih kepada Husnia Mukhtar, Nurbaya dan Tasrik, selaku laboran Laboratorium Pendidikan Kimia FKIP Universitas Tadulako serta teman-teman khususnya Stefhanny Galib yang telah membantu dalam pelaksanaan penelitian ini.

\section{Referensi}

Achmad, S. A. (1986). Kimia organik bahan alam. Jakarta: Karunika Jakarta.

Budi, I. M., \& Paimin, F. R. (2005). Buah merah. Jakarta: Penebar Swadaya.

Day, R. A. (2003). Analisis kimia kuantitatif (6 ed.). Jakarta: Erlangga.
Harborne, J. B. (1987). Phytochemical methods (K. Padmawinata \& I. Sudiro, Trans.). Bandung: ITB.

Makaruku, H. M. (2008). Kajian agronomi dan pemanfaatan buah merah (pandanus conoideus Lamk.). Ambon: Universitas Pattimura.

Molyneux, P. (2004). The use of the stable free radicals diphenylpicrylhydrazyl (DPPH) for estimating antioxidant activity. Songklanakarin Journal of Science Technology, 26(2), 211-219.

Rahman, Usman, H., \& Ahmad, A. (2008). Isolasi, identifikasi dan uji bioaktivitas metabolit sekuder ekstrak kloroform spons petrosia alfiani dari Kepulauan Barrang Lompo. Makassar: Universitas Hasanuddin.

Rohman, A., Riyanto, S., Yuniarti, N., Saputra, W. R., Utami, R., \& Mulatsih, W. (2010). Antioxidant activity total phenolic and total flavaonoid of extracts and fractions of red fruit (pandanus conoideus Lamk.). International Food Research Journal, 17, 97-106.

Sa'adah, L. (2010). Isolasi dan identifikasi senyawa tanin dari daun belimbing wuluh (Averrhoa bilimbi L.). Malang: Universitas Islam Negeri Maulana Malik Ibrahim.

Sangkala, S. A. , Jura, M. R., \& Tangkas, I. M. (2014). Uji aktivitas antioksidan buah merah (pandanus conoideus L.) di daerah Sulawesi Tengah. Jurnal Akademika Kimia, 3(4), 198-205.

Silalahi, N. K. A. F., \& Kusharyanti, I. U. T. (2006). Uji aktivitas antioksidan dan buah merah (pandanus conoideus L.) di daerah Sulawesi Tengah. Universitas Tanjung Pura.

Suharto, E. (2004). Struktur biji, sifat fisik biji, dan karakteristik benih kayu Afrika (Maesopris eminii Engl.) provenan Padang Jaya. Akta Agrosia, 7(1), 24-32.

Suryanto, E. (2012). Fitokimia antioksidan. Surabaya: Putra Media Nusantara.

Yulianti, I. D., Walanda, D. K., \& Said, I. (2015). Analisis kadar kalium, kalsium dan natrium dalam buah merah (Pandanus baccari) asal Kabupaten Poso sebagai alternatif peluruh batu ginjal. Jurnal Akademika Kimia, 4(1), 50-55.

Zao, Y., Lu, Y., \& Wei, D. (2004). Antioxidant activity of a flavonoid-rich extract of Hypericum perforatum L. in vitro. Journal of Agricultural and Food Chemistry, 52(16), 5032-5039. 